\title{
Antioxidant activity and chemical composition of Cichorium spinosum $L$. in relation to nitrogen rate
}

\author{
S. Petropoulos ${ }^{1}$, Â. Fernandes ${ }^{2}$, A. Karkanis ${ }^{1}$, G. Ntasti ${ }^{3}$, L. Barros ${ }^{2}$ and I.C.F.R. Ferreira ${ }^{2}$ \\ ${ }^{1}$ School of Agricultural Sciences, Department of Agriculture, Crop Production and Rural Environment, University \\ of Thessaly, Volos, Greece; ${ }^{2}$ Centro de Investigação de Montanha (CIMO), ESA, Instituto Politécnico de Bragança, \\ Bragança, Portugal; ${ }^{3}$ Faculty of Crop Science, Agricultural University of Athens, Athens, Greece.
}

\begin{abstract}
In the present study, the effect of nitrogen ( $\mathrm{N}$ ) application rate on phenolic compounds content and antioxidant activity of Cichorium spinosum L. leaves was examined. Seeds were sown in seed trays containing peat and young seedlings were transplanted in 2-L plastic pots containing soil. Four nitrogen rates were applied, namely: a) control (no added N), b) $200 \mathrm{mg} \mathrm{L}^{-1}$ of total $\mathrm{N}$, c) $400 \mathrm{mg} \mathrm{L}^{-1}$ of total $\mathrm{N}$, and d) $600 \mathrm{mg} \mathrm{L}^{-1}$ of total N. Plants were harvested when rosettes reached marketable size. The results showed that the most abundant phenolic compounds of leaves extracts were chlorogenic acid, chicoric acid and kaempferol-3-O-glucuronide, while increasing nitrogen rates resulted in a significant decrease of the main phenolic compounds content. Similarly, the application of $600 \mathrm{mg} \mathrm{L}^{-1}$ of total nitrogen resulted in significant decrease of antioxidant potency of leaf extracts comparing to control, regardless of the performed assay, whereas for all the assays except for DPPH the application of $200 \mathbf{~ m g}$ $\mathrm{L}^{-1}$ showed the best antioxidant properties. In conclusion, although the application of high nitrogen rates is tempting in order to achieve higher yields, rates higher than 200 $\mathrm{mg} \mathrm{L}^{-1}$ are not recommended for $C$. spinosum cultivation, since a significant decrease of the bioactive compounds is observed that could compromise the quality of the final product.
\end{abstract}

Keywords: nitrates, phenolic compounds, 5-O-caffeoylquinic acid, chicoric acid, flavonoids

\section{INTRODUCTION}

The application of fertilizers is essential in commercial agriculture in order to obtain high yields of marketable quality. Especially for nitrogen fertilizers, their use is among the highest among various agrochemicals and they are considered as one of the key factors for increasing yields. However, this usually results in irrational use with excessive amounts of fertilizers being used aiming toward yields that exceed the crop potential. Apart from the unnecessary production cost increase, excessive use of fertilizers may have detrimental effects on the environment and the quality of the final product by increasing nitrates content in plant tissues. According to Hord et al. (2009), leafy vegetables tend to accumulate nitrates in amounts which depend mostly on application rates and the species. In addition, the various forms of nitrogen may affect leafy vegetables quality in other ways than increase nitrates content, since it is involved in many biosynthetic pathways, such as polyphenols (Lombardo et al., 2017), including flavonoids (Fallovo et al., 2011; Chrysargyris et al., 2017). Moreover, antioxidant activity has also been reported to be affected by nitrogen fertilization in various species, such as kale (Łata, 2014), spearmint (Chrysargyris et al., 2017), and pumpkin (Oloyede et al., 2012, 2014).

Therefore, the aim of the present study was to evaluate the effect of nitrogen rates on the antioxidant activity and phenolic compounds content of $C$. spinosum leaves.

\section{MATERIALS AND METHODS}

\section{Plant material}

Plants were grown from seeds as previously described by Anesti et al. (2016). More specifically, seeds were sown in seed trays on December 15, 2015 containing peat by Vianame 
S.A. (Timpaki, Greece). Seedlings of Cichorium spinosum L. were transplanted at the $3^{\text {rd }}$-leaf stage on February 15, 2016 in 2-L pots containing peat (Klassman-Deilmann KTS2, 1.0 L) and perlite $(1.0 \mathrm{~L})$. Plants were fertilized through the irrigation water with four nitrogen rates, namely: a) Control (no added N), b) $200 \mathrm{mg} \mathrm{L}^{-1}$ of total N, c) $400 \mathrm{mg} \mathrm{L}^{-1}$ of total N, and d) 600 $\mathrm{mg} \mathrm{L}^{-1}$ of total N. All fertilization treatments $\left(200,400\right.$, and $600 \mathrm{mg} \mathrm{L}^{-1}$ of nitrogen) were prepared by adding the same amount of a water soluble synthetic fertilizer (Atlas 20-20-20 + TE; Gavriel S.A., Greece) in order to have $200 \mathrm{mg} \mathrm{L}^{-1}$ of N-P-K in all the treatments, while for the treatments of 400 and $600 \mathrm{ppm}$, the rest of the nitrogen (200 and $400 \mathrm{mg} \mathrm{L}^{-1}$, respectively) was added in the form of ammonium nitrate (34.5-0-0; N-P-K). Plants were harvested when rosettes reached a marketable size. After harvest samples of raw leaves were stored at $-80^{\circ} \mathrm{C}$ and lyophilized for further chemical composition analyses.

\section{Antioxidant activity assays}

One gram of lyophilized material was extracted twice for $1 \mathrm{~h}$ in a magnetic stirrer plate $\left(25^{\circ} \mathrm{C}\right.$ at $\left.150 \mathrm{rpm}\right)$, with $30 \mathrm{~mL}$ of methanol/water $(80: 20, \mathrm{v} / \mathrm{v})$, filtered through a Whatman No. 4 paper and vacuum-dried in a rotary evaporator (Büchi R-210, Switzerland) at $40^{\circ} \mathrm{C}$ to remove the methanol. The extracts were further frozen and lyophilized, re-dissolved in methanol/water (80:20, v/v) for in vitro antioxidant activity assays at a final concentration of $20 \mathrm{mg} \mathrm{mL}^{-1}$, and further diluted to different concentrations, as previously described by Petropoulos et al. (2015).

DPPH radical-scavenging activity was evaluated with an ELX800 microplate reader (Bio-Tek Instruments, Inc., USA), and calculated as a percentage of DPPH discoloration using the formula: $\left[\left(A_{D P P H}-A_{S}\right) / A_{D P P H}\right] \times 100$, where $A_{S}$ is the absorbance of sample solution at $515 \mathrm{~nm}$, and $A_{D P P H}$ is the absorbance of the DPPH solution. Reducing power was evaluated by the capacity to convert $\mathrm{Fe}^{3+}$ to $\mathrm{Fe}^{2+}$, measuring the absorbance at $690 \mathrm{~nm}$ in the abovementioned microplate reader. Inhibition of $\beta$-carotene bleaching was evaluated though the $\beta$ carotene/linoleate assay; the neutralization of linoleate free radicals avoids $\beta$-carotene bleaching, which is measured by the formula: $\beta$-carotene absorbance after $2 \mathrm{~h}$ of assay/initial absorbance $\times 100$. Lipid peroxidation inhibition in porcine brain homogenates was evaluated by the decreasing in thiobarbituric acid reactive substances (TBARS); the color intensity of the malondialdehyde-thiobarbituric acid (MDA-TBA) was measured by its absorbance at 532 $\mathrm{nm}$; the inhibition ratio (\%) was calculated using the following formula: $[(\mathrm{A}-\mathrm{B}) / \mathrm{A}] \times 100 \%$, where $A$ and $B$ were the absorbance of the control and the sample solution, respectively. ${ }^{16}$ The results were expressed in $\mathrm{EC}_{50}$ values (sample concentration providing $50 \%$ of antioxidant activity or 0.5 of absorbance in the reducing power assay) for antioxidant activity and Trolox was used as a positive control.

\section{Phenolic compounds analysis}

The above-mentioned extracts were re-dissolved in methanol/water $(80: 20, \mathrm{v} / \mathrm{v})$ at a final concentration of $30 \mathrm{mg} \mathrm{mL}^{-1}$ and filtered through a $0.45 \mu \mathrm{m}$ Whatman syringe filter, transferred to amber color HPLC vial for phenolic compound analysis.

The phenolic profile was determined by LC-DAD-ESI/MSn (Dionex Ultimate 3000 UPLC, Thermo Scientific, USA), following a procedure previously described by Bessada et al. (2016). For double online detection, 280, 330 and $370 \mathrm{~nm}$ were used as preferred wavelengths for DAD and in a mass spectrometer (MS) connected to HPLC system. The MS detection was performed in negative mode, using a Linear Ion Trap LTQ XL mass spectrometer (ThermoFinnigan, USA) equipped with an ESI source. Phenolic compounds identification was performed using standard compounds when available, by comparison with their retention times, UV-vis and mass spectra, and by comparing the obtained information with available data reported in the literature giving a tentative identification. For quantitative analysis, a calibration curve for each available phenolic standard was constructed based on the UV signal. When commercial standards were not available, the quantification was performed through the calibration curve of the most similar available standard. The results were expressed as $\mathrm{mg}$ $\mathrm{g}^{-1}$ of extract. 


\section{Statistical analyses}

For chemical composition analyses, three samples were analyzed for each treatment, while all the assays were carried out in triplicate. The results are expressed as mean values and standard deviations (SD), and analyzed using one-way analysis of variance (ANOVA) for the main effects, followed by Tukey's HSD test $(p=0.05)$ for means comparison. Statistical analysis was carried out with Statgraphics 5.1. plus (Statpoint Technologies, Inc., USA).

\section{RESULTS AND DISCUSSION}

The antioxidant properties of $C$. spinosum leaves in relation to nitrogen application rates are presented in Table 1 . The results show that the highest antioxidant activity of leaf extracts was observed when $200 \mathrm{mg} \mathrm{L}^{-1}$ of total nitrogen were applied for all the studied assays, except for DPPH scavenging activity assay where control treatment showed the best results. Therefore, high nitrogen rates, although they may increase fresh weight and yield, they also have a negative effect on antioxidant properties. Similar results have been reported for other vegetables species, where high nitrogen application rates decreased significantly antioxidant activity (Rodríguez-Hidalgo et al., 2010; Łata, 2014; Oloyede et al., 2014; Chrysargyris et al., 2017). According to a previous study of our team (Petropoulos et al., 2016), nitrogen rates up to $400 \mathrm{mg} \mathrm{L}^{-1}$ result in high yields without compromising nutritional value of the final product. However, in order to retain their antioxidant properties, plants should be fertilized with nutrient solutions with concentrations of $200 \mathrm{ppm} \mathrm{L}^{-1}$ of total nitrogen.

Table 1. Antioxidant properties of Cichorium spinosum leaves in relation to nitrogen application rates.

\begin{tabular}{|c|c|c|c|c|}
\hline & \multirow{2}{*}{$\begin{array}{l}\text { Reducing power } \\
\text { Ferricyanidel } \\
\text { Prussian blue } \\
\text { (EC } \text { ( }_{50} \text {; } \mathrm{mL}^{-1} \text { ) }\end{array}$} & \multicolumn{2}{|c|}{ Radical scavenging activity } & \multirow{2}{*}{$\begin{array}{c}\text { Lipid peroxidation } \\
\text { inhibition } \\
\text { TBARS } \\
\left(E_{50} ; \mathrm{mg} \mathrm{mL}^{-1}\right)\end{array}$} \\
\hline & & $\begin{array}{c}\text { DPPH scavenging } \\
\text { activity } \\
\left(E_{50} ; \mathrm{mg} \mathrm{mL}^{-1}\right)\end{array}$ & $\begin{array}{c}\beta \text {-carotenel } \\
\text { linoleate } \\
\left(\mathrm{EC}_{50} ; \mathrm{mg} \mathrm{mL}^{-1}\right)\end{array}$ & \\
\hline Control & $0.835 \pm 0.003 b$ & $1.39 \pm 0.07 d$ & $0.79 \pm 0.04 b$ & $0.46 \pm 0.02 \mathrm{~b}$ \\
\hline $200 \mathrm{mg} \mathrm{L}-1$ & $0.728 \pm 0.020 \mathrm{c}$ & $1.62 \pm 0.06 \mathrm{c}$ & $0.75 \pm 0.01 \mathrm{c}$ & $0.35 \pm 0.008 d$ \\
\hline $400 \mathrm{mg} \mathrm{L}^{-1}$ & $0.839 \pm 0.006 a b$ & $2.23 \pm 0.10 b$ & $0.79 \pm 0.02 b$ & $0.38 \pm 0.02 c$ \\
\hline $600 \mathrm{mg} \mathrm{L}-1$ & $0.849 \pm 0.008 a$ & $2.93 \pm 0.07 a$ & $1.00 \pm 0.03 a$ & $0.54 \pm 0.02 a$ \\
\hline
\end{tabular}

Means in the same column followed by different letters are significantly different according to Tukey HSD test at $p<0.05$.

The detected phenolic compounds and their identification data are presented in Table 2. Identification of phenolic compounds was carried out and cross checked through their mass spectrum and UV absorption. The main phenolic compounds were chicoric acid and kaempferol-3-O-glucuronide, followed by 5- $O$-caffeoylquinic acid, isorhamnetin-3-Oglucuronide and quercetin-3-O-glucuronide (Table 3). According to the results, the application of nitrogen through the irrigation water has a negative effect on phenolic compounds content. Moreover, phenolic composition was also affected, with increasing nitrogen rates resulting in lower contents of both phenolic acids and flavonoids. In particular, chicoric acid, quercetin-3$O$-glucuronide, kaempferol-3-O-glucuronide and isorhamnetin-3-O-glucuronide decreased, whereas kaempferol- $O$-glucuronide increased and 5-O-caffeoylquinic acid presented fluctuating trends. Therefore, in general, increasing nitrogen application rates results in a significant decrease of phenolic compounds content, which could have a negative effect on bioactivity of $C$. spinosum leaves. Similar results have been reported by Petropoulos et al. (2017), who also identified chicoric acid and 5-O-caffeoylquinic acid as the main phenolic compounds of $C$. spinosum leaves, while Lombardo et al. (2017) and Oloyede et al. (2012) reported that increasing nitrogen rates resulted in the decrease of total phenolic compounds content in globe artichoke and pumpkin, respectively. 


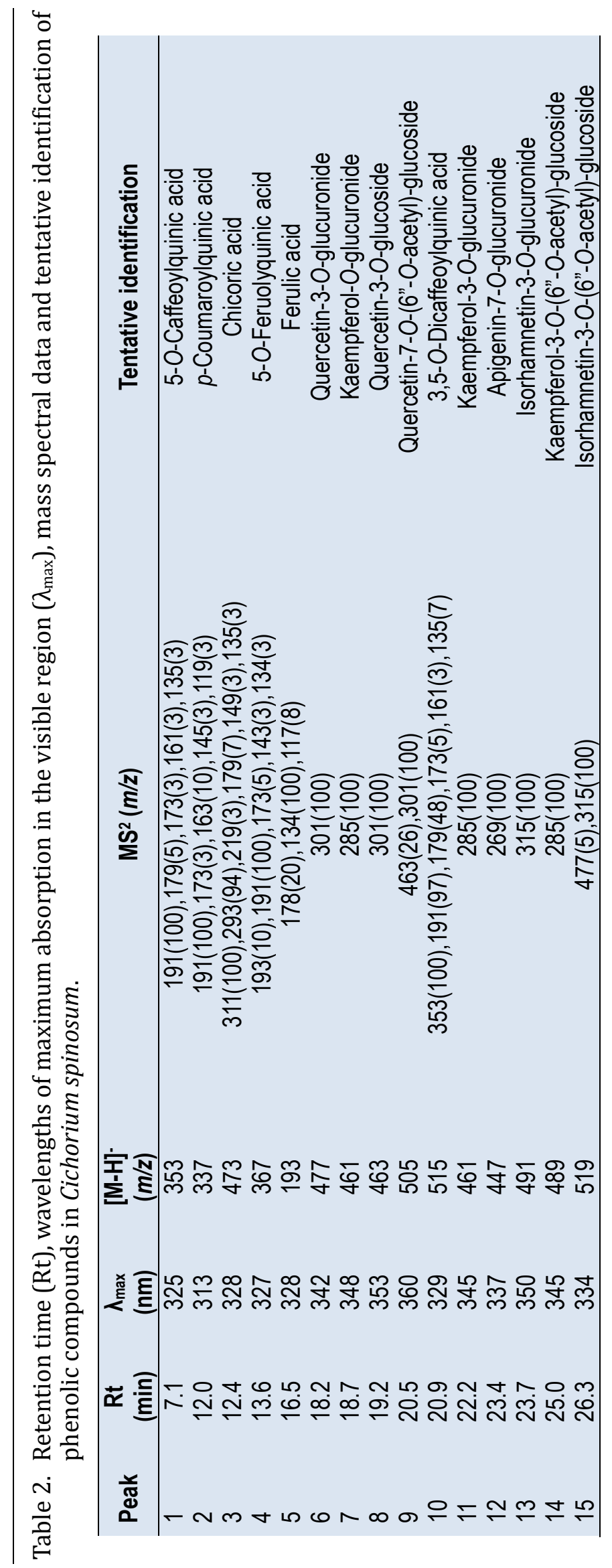


Table 3. Phenolic compounds quantification of Cichorium spinosum ( $\mathrm{mg} \mathrm{g}^{-1}$ extract; mean \pm SD) in relation to nitrogen application rates.

\begin{tabular}{|c|c|c|c|c|}
\hline \multirow{2}{*}{ Phenolic compound } & \multicolumn{4}{|c|}{ Nitrogen rates } \\
\hline & Control & $200 \mathrm{mg} \mathrm{L}^{-1}$ & $400 \mathrm{mg} \mathrm{L}^{-1}$ & $600 \mathrm{mg} \mathrm{L}^{-1}$ \\
\hline 5-0-Caffeoylquinic acida & $3.13 \pm 0.05 a$ & $1.97 \pm 0.09 c$ & $1.71 \pm 0.03 d$ & $2.862 \pm 0.008 \mathrm{~b}$ \\
\hline$p$-Coumaroylquinic acidb & $0.330 \pm 0.002 \mathrm{c}$ & $0.360 \pm 0.002 b$ & $0.473 \pm 0.001 a$ & $0.272 \pm 0.002 d$ \\
\hline Chicoric acidc & $13.96 \pm 0.07 a$ & $8.66 \pm 0.07 \mathrm{~b}$ & $8.33 \pm 0.04 c$ & $3.25 \pm 0.02 d$ \\
\hline 5-O-Feruolyquinic acidd & $0.83 \pm 0.01 b$ & $0.752 \pm 0.001 \mathrm{c}$ & $0.92 \pm 0.03 a$ & $0.530 \pm 0.001 d$ \\
\hline Ferulic acidd & $0.41 \pm 0.02 \mathrm{a}$ & $0.128 \pm 0.002 b$ & $0.138 \pm 0.003 b$ & $0.090 \pm 0.001 \mathrm{c}$ \\
\hline Quercetin-3-O-glucuronide & $2.21 \pm 0.03 a$ & $1.76 \pm 0.02 b$ & $1.81 \pm 0.01 \mathrm{~b}$ & $1.164 \pm 0.001 \mathrm{c}$ \\
\hline Kaempferol-O-glucuronide & $1.651 \pm 0.004 d$ & $2.47 \pm 0.02 b$ & $3.16 \pm 0.02 a$ & $2.26 \pm 0.03 c$ \\
\hline Quercetin-3-0-glucoside ${ }^{e}$ & $0.71 \pm 0.03 \mathrm{a}$ & nd & $0.39 \pm 0.01 b$ & nd \\
\hline Quercetin-7-0-(6"-0-acetyl)-glucosidee & $0.761 \pm 0.005 a$ & $0.328 \pm 0.001 \mathrm{~b}$ & $0.321 \pm 0.004 b$ & $0.255 \pm 0.001 \mathrm{c}$ \\
\hline 3,5-0-Dicaffeoylquinic acida & $0.79 \pm 0.05 a$ & $0.298 \pm 0.006 b$ & $0.307 \pm 0.006 \mathrm{~b}$ & $0.256 \pm 0.004 b$ \\
\hline Kaempferol-3-0-glucuronidef & $5.69 \pm 0.01 \mathrm{a}$ & $2.70 \pm 0.02 b$ & $2.50 \pm 0.01 \mathrm{c}$ & $1.776 \pm 0.007 d$ \\
\hline Apigenin-7-0-glucuronideg & $0.322 \pm 0.003 \mathrm{c}$ & $0.217 \pm 0.002 d$ & $0.493 \pm 0.001 a$ & $0.408 \pm 0.002 \mathrm{~b}$ \\
\hline Isorhamnetin-3-0-glucuronide & $1.860 \pm 0.003 a$ & $0.558 \pm 0.002 \mathrm{c}$ & $0.612 \pm 0.005 b$ & $0.518 \pm 0.003 d$ \\
\hline Kaempferol-3-0-(6"-0-acetyl)-glucosidef & $1.17 \pm 0.03 \mathrm{a}$ & $0.35 \pm 0.01 b$ & $0.388 \pm 0.006 \mathrm{~b}$ & $0.296 \pm 0.003 c$ \\
\hline |sorhamnetin-3-0-(6"-0-acetyl)-glucosidee & $0.35 \pm 0.01 \mathrm{a}$ & $0.218 \pm 0.006 \mathrm{~b}$ & $0.224 \pm 0.004 b$ & $0.209 \pm 0.002 b$ \\
\hline Total phenolic acids & $19.4 \pm 0.2 \mathrm{a}$ & $12.8 \pm 0.2 b$ & $11.88 \pm 0.03 b$ & $7.26 \pm 0.02 c$ \\
\hline Total flavonoids & $14.723 \pm 0.003 a$ & $8.60 \pm 0.05 c$ & $9.902 \pm 0.001 b$ & $6.89 \pm 0.03 d$ \\
\hline Total phenolic compounds & $34.2 \pm 0.2 \mathrm{a}$ & $20.8 \pm 0.2 \mathrm{c}$ & $21.78 \pm 0.04 b$ & $14.15 \pm 0.01 \mathrm{~d}$ \\
\hline
\end{tabular}

Means in the same row followed by different letters are significantly different according to Tukey HSD test at $p<0.05$. nd - not detected.

Calibration curves used: achlorogenic acid ( $\left.y=168823 x-161172 ; R^{2}=0.999\right)$ : bp-coumaric acid $\left(y=301950 x+6966.7 \cdot R^{2}=0.999\right)$ : ${ }^{\circ}$ caffeic acid $\left(y=388345 x+406369\right.$; $\left.R^{2}=0.994\right)$ : dferulic acid $\left(y=633126 \mathrm{x}-185462 ; R^{2}=0.999\right)$; equercetin-3-O-glucoside ( $\left.\mathrm{y}=34843 \mathrm{x}-160173 ; R^{2}=0.999\right) ;$; kaempferol-3-O-rutinoside $\left(\mathrm{y}=11117 \mathrm{x}+30861 ; R^{2}=0.999\right) ;$ gapigenin-7-0-glucoside $(\mathrm{y}$ $\left.=10683 x-45794 ; R^{2}=0.996\right)$ 
In addition, Brieudes et al. (2016) reported chicoric acid as the main phenolic compound in water decoctions of $C$. spinosum and $C$. intybus leaves, while Jaiswal and Kuhnert (2011) also identified this phenolic acid in C. intybus. 5-0-Caffeoylquinic acid has also been previously reported in $C$. intybus leaves in other studies (Rossetto et al., 2005; Jaiswal et al., 2011; Carazzone et al., 2013; Ferioli et al., 2015). Antioxidant properties of $C$. spinosum has been associated with phenolic compounds, especially chicoric acid, which has been suggested as the main antioxidant compound of $C$. spinosum (Brieudes et al., 2016). In another study, with wild edible greens, Pereira et al. (2011) also demonstrated a positive linear correlation of phenolic compounds content and antioxidant activity, indicating however selectivity between phenolic compound classes and antioxidant activity assays.

\section{CONCLUSIONS}

Considering that $C$. spinosum is a species recently introduced for commercial cultivation, most farmers apply fertilization regimes, based on their experience from other leafy vegetables or by empirical information. Although high nitrogen rates may increase fresh weight and total yield, they also have a negative effect on bioactive compounds content and antioxidant properties of $C$. spinosum leaves. Therefore, there must be a compromise between yield and phytochemicals content. Therefore, in the case of $C$. spinosum leaves, low medium nitrogen rates $\left(200 \mathrm{mg} \mathrm{L}^{-1}\right)$ should be applied in order to achieve the best balance between yield, antioxidant capacity and/or phytonutrient content.

\section{Literature cited}

Anesti, S., Fasoli, K., Petropoulos, S., Ntatsi, G., Antoniadis, V., and Ferreira, I.C.F.R. (2016). Effect of ammonium fertilizer on growth and quality of Cichorium spinosum plants. Paper presented at: VII International Scientific Agriculture Symposium "Agrosym 2016".

Bessada, S.M.F., Barreira, J.C.M., Barros, L., Ferreira, I.C.F.R., and Oliveira, M.B.P.P. (2016). Phenolic profile and antioxidant activity of Coleostephus myconis (L.) Rchb.f.: an underexploited and highly disseminated species. Ind. Crops Prod. 89, 45-51 https://doi.org/10.1016/j.indcrop.2016.04.065.

Brieudes, V., Angelis, A., Vougogiannopoulou, K., Pratsinis, H., Kletsas, D., Mitakou, S., Halabalaki, M., and Skaltsounis, L.A. (2016). Phytochemical analysis and antioxidant potential of the phytonutrient-rich decoction of Cichorium spinosum and C. intybus. Planta Med. 82 (11-12), 1070-1078 https://doi.org/10.1055/s-0042-107472. PubMed

Carazzone, C., Mascherpa, D., Gazzani, G., and Papetti, A. (2013). Identification of phenolic constituents in red chicory salads (Cichorium intybus) by high-performance liquid chromatography with diode array detection and electrospray ionisation tandem mass spectrometry. Food Chem. 138 (2-3), 1062-1071 https://doi.org/10.1016/ j.foodchem.2012.11.060. PubMed

Chrysargyris, A., Nikolaidou, E., Stamatakis, A., and Tzortzakis, N. (2017). Vegetative, physiological, nutritional and antioxidant behavior of spearmint (Mentha spicata L.) in response to different nitrogen supply in hydroponics. J. Appl. Res. Med. Aromat. Plants 6, 52-61 https://doi.org/10.1016/j.jarmap.2017.01.006.

Fallovo, C., Schreiner, M., Schwarz, D., Colla, G., and Krumbein, A. (2011). Phytochemical changes induced by different nitrogen supply forms and radiation levels in two leafy Brassica species. J. Agric. Food Chem. 59 (8), 41984207 https://doi.org/10.1021/jf1048904. PubMed

Ferioli, F., Manco, M.A., and D'Antuono, L.F. (2015). Variation of sesquiterpene lactones and phenolics in chicory and endive germplasm. J. Food Compos. Anal. 39, 77-86 https://doi.org/10.1016/j.jfca.2014.11.014.

Hord, N.G., Tang, Y., and Bryan, N.S. (2009). Food sources of nitrates and nitrites: the physiologic context for potential health benefits. Am. J. Clin. Nutr. 90 (1), 1-10 https://doi.org/10.3945/ajcn.2008.27131. PubMed

Jaiswal, R., and Kuhnert, N. (2011). Identification and characterization of five new classes of chlorogenic acids in burdock (Arctium lappa L.) roots by liquid chromatography/tandem mass spectrometry. Food Funct. 2 (1), 63-71 https://doi.org/10.1039/C0FO00125B. PubMed

Jaiswal, R., Kiprotich, J., and Kuhnert, N. (2011). Determination of the hydroxycinnamate profile of 12 members of the Asteraceae family. Phytochemistry 72 (8), 781-790 https://doi.org/10.1016/j.phytochem.2011.02.027. PubMed

Łata, B. (2014). Variability in enzymatic and non-enzymatic antioxidants in red and green-leafy kale in relation to soil type and N-level. Sci. Hortic. (Amsterdam) 168, 38-45 https://doi.org/10.1016/j.scienta.2014.01.009.

Lombardo, S., Restuccia, C., Muratore, G., Barbagallo, R.N., Licciardello, F., Pandino, G., Scifò, G.O., Mazzaglia, A., 
Ragonese, F., and Mauromicale, G. (2017). Effect of nitrogen fertilisation on the overall quality of minimally processed globe artichoke heads. J. Sci. Food Agric. 97 (2), 650-658 https://doi.org/10.1002/jsfa.7784. PubMed

Oloyede, F.M., Agbaje, G.O., Obuotor, E.M., and Obisesan, I.O. (2012). Nutritional and antioxidant profiles of pumpkin (Cucurbita pepo Linn.) immature and mature fruits as influenced by NPK fertilizer. Food Chem. 135 (2), 460-463 https://doi.org/10.1016/j.foodchem.2012.04.124. PubMed

Oloyede, F.M., Adebooye, O.C., and Obuotor, E.M. (2014). Planting date and fertilizer affect antioxidants in pumpkin fruit. Sci. Hortic. (Amsterdam) 168, 46-50 https://doi.org/10.1016/j.scienta.2014.01.012.

Pereira, C., Barros, L., Carvalho, A.M., and Ferreira, I.C.F.R. (2011). Nutritional composition and bioactive properties of commonly consumed wild greens: potential sources for new trends in modern diets. Food Res. Int. 44 (9), $2634-$ 2640 https://doi.org/10.1016/j.foodres.2011.05.012.

Petropoulos, S.A., Fernandes, Â., Barros, L., Ferreira, I.C.F.R., and Ntatsi, G. (2015). Morphological, nutritional and chemical description of "Vatikiotiko", an onion local landrace from Greece. Food Chem. 182, 156-163 https://doi.org/10.1016/j.foodchem.2015.03.002. PubMed

Petropoulos, S., Fernandes, Â., Karkanis, A., Antoniadis, V., Barros, L., and Ferreira, I.C.F.R. (2016). Yield and chemical composition of Cichorium spinosum L. in relation to nitrogen rate. Paper presented at: Vienna International Science Conferences \& Events Association, Plant Nutrition, Growth \& Environment Interactions II (Vienna, Austria).

Petropoulos, S.A., Levizou, E., Ntatsi, G., Fernandes, Â., Petrotos, K., Akoumianakis, K., Barros, L., and Ferreira, I.C.F.R. (2017). Salinity effect on nutritional value, chemical composition and bioactive compounds content of Cichorium spinosum L. Food Chem. 214, 129-136 https://doi.org/10.1016/j.foodchem.2016.07.080. PubMed

Rodríguez-Hidalgo, S., Artés-Hernández, F., Gómez, P.A., Fernández, J.A., and Artés, F. (2010). Quality of fresh-cut baby spinach grown under a floating trays system as affected by nitrogen fertilisation and innovative packaging treatments. J. Sci. Food Agric. 90 (6), 1089-1097 https://doi.org/10.1002/jsfa.3926. PubMed

Rossetto, M., Lante, A., Vanzani, P., Spettoli, P., Scarpa, M., and Rigo, A. (2005). Red chicories as potent scavengers of highly reactive radicals: a study on their phenolic composition and peroxyl radical trapping capacity and efficiency. J. Agric. Food Chem. 53 (21), 8169-8175 https://doi.org/10.1021/jf051116n. PubMed 
